\section{Michał Kulbacki}

(D) https://orcid.org/0000-0002-9203-3904

Institute of World Economy

Collegium of World Economy

SGH Warsaw School of Economics

michal.b.kulbacki@gmail.com

\section{Adrian Michalczuk}

(D) https://orcid.org/0000-0001-8872-9047

Department of European

Integration and Legal Studies

Collegium of World Economy

SGH Warsaw School of Economics

adrianmichalczukk@gmail.com

\title{
Regional trade integration in Central and Eastern Europe: State of play after 15 years of EU membership
}

Accepted by Editor Ewa Ziemba | Received: January 30, 2021 | Revised: April 20, 2021; May 15, 2021 | Accepted: May 25, 2021 | Published: July 1, 2021.

(C) 2021 Author(s). This article is licensed under the Creative Commons Attribution-NonCommercial 4.0 license (https://creativecommons.org/licenses/by-nc/4.0/)

\begin{abstract}
Aim/purpose - The purpose of this paper is to analyze regional trade integration of 10 Central and Eastern Europe countries (CEE-10) during the 2004-2018 period, identify regional- and country-level integration patterns and attribute them to potential causes indicated by the literature.

Design/methodology/approach - The paper employed literature-based trade integration indicators to data on CEE-10 trade in goods and conducted a review of empirical studies investigating trade integration determinants in CEE.

Findings - The results evidence an advancing regional trade integration with decreasing pace in recent years. The study has found all CEE countries to be more integrated with the region. Moreover, several integration patterns have been distinguished.

Research implications/limitations - The study found a significant literature gap concerning CEE regional trade integration and its determinants. Its limitations refer to: lack of product-groups-level trade data and narrow scope of trade flows (in goods only).

Originality/value/contribution - The paper's value-added stems from a multi-perspective analysis of the CEE regional trade integration and a discussion of region- and country-level integration patterns.
\end{abstract}

Keywords: Central and Eastern Europe, regional trade integration, trade integration, global value chains, economic integration.

JEL Classification: F14, F15, F60.

Cite as: Kulbacki, M., \& Michalczuk, A. (2021). Regional trade integration in Central and Eastern Europe: State of play after 15 years of EU membership. Journal of Economics \& Management, 43, 225-250. https://doi.org/10.22367/jem.2021.43.11 


\section{Introduction}

In the face of the COVID-19 pandemic, the Central and Eastern Europe (CEE) countries "weathering it (the crisis) better than much of Europe" (Belka \& Nagy-Mohacsi, 2020), make the question of the future potential for the region to become a European post-COVID-19 growth engine fairly justified. Poland exceeding Portugal and Czechia outpacing Spain in GDP per capita terms in 2019, marked another milestone on the region's growth path (World Bank, 2020). With significantly higher trade openness than the rest of the EU (Grela et al., 2017), the exchange of goods and services constitutes a major growth factor for the CEE region.

The East-West trade integration (between CEE-10 and EU-15 ${ }^{1}$ ) in the post-accession period, contributing to the region's rising trade openness, ${ }^{2}$ has been evidenced extensively in research (i.e., Ravishankar \& Stack, 2014). On the contrary, little to no attention has been devoted to another potential source of trade openness and thus the potential region's economic success factor - intra-regional trade integration. ${ }^{3}$ With the growth of the latter integration not being implied by rising trade openness itself, the existing literature has identified a multitude of factors behind an advancing tightening of economic relations between the CEE countries (in trade area in particular).

In general, a significant research gap concerning the CEE-10 trade integration has been identified, as the majority of studies found focus on integration between CEE and EU-15. The paper's value-added stems from (i) a holistic view of CEE trade integration obtained based on multiple literature-based indicators, and (ii) a discussion of region- and country-level patterns in analyzed data. To the best of our knowledge, a similar paper examining both regional- and country-level CEE trade integration from multiple perspectives has not yet been published.

1 In this paper CEE-10 is defined as a group of the New Members States (NMS) of the EU from the CEE region, including Bulgaria, Czechia, Estonia, Hungary, Latvia, Lithuania, Poland, Romania, Slovakia, and Slovenia. The EU-15 is a group of the 'old' Member States, including Austria, Belgium, Denmark, Finland, France, Germany, Greece, Ireland, Italy, Luxembourg, Netherlands, Portugal, Spain, Sweden and the United Kingdom.

2 According to Grela et al. (2017), trade openness of the CEE countries was rising steadily in years 1995-2019, with only a short setback, however v-shaped, resulting from the financial crisis. Data referring to six CEE countries (Bulgaria, Czechia, Hungary, Poland, Romania, and Slovakia) seem to constitute a valid approximation for CEE-10 in relation to trade openness dynamics.

3 Similarly to the East-West trade relations, intra-regional trade liberalization began already in the 1990s with the introduction of Central European Free Trade Agreement (CEFTA) and Baltic Free Trade Agreement (BFTA). Until 1999 all countries analyzed in this publication were party to one of the two described agreements. Refer to Wilhelmsson (2006) and Molendowski (2007) for more details. 
The paper aims to (i) analyze the regional trade integration of the CEE-10 countries that joined the EU in 2004-2007 in the period of 2004-2018 and (ii) identify regional- and country-level integration patterns and attribute them to potential causes indicated by the literature. To fulfil the respective goals, in the following paper (i) multiple literature-based indicators of regional trade integration and its dynamics have been calculated; (ii) literature review on factors influencing the CEE trade integration has been conducted.

The paper is structured as follows. Section 2 is divided in two major parts and contains (2.1) a theoretical framework on factors influencing trade and review of empirical studies relevant for CEE; (2.2.) a literature review of studies examining the CEE-10 trade integration dynamics, similarly to the following piece. Methodology (Section 3) presents an overview of used indicators, constituting a base for Section 4, containing an in-depth empirical assessment of CEE trade integration level and dynamics. In Discussion (Section 5), region- and country-level integration patterns from empirical work are indicated and their potential causes discussed against existing literature findings. The paper closes with conclusions (Section 6).

\section{Literature review}

\subsection{Literature review on regional trade integration and theoretical framework}

\subsubsection{Theoretical framework for regional trade integration and its determinants}

As the paper concentrates on 'regional trade integration', understood as trade integration between the CEE-10 countries, one has to point out to the lack of unified definition of the term. On the one hand, there is a rather unbiased understanding of 'trade integration' in the literature, which could be defined as a degree of each other's market penetration between two or more countries (Nilsson, 2000). On the other, varying application of the term 'region' in the trade literature (i.e., as a whole continent or as a group of countries located in the same geographic area and/or bounded with some form of economic cooperation like ASEAN, or MERCOSUR), renders (i) measuring regional trade integration with dedicated indicators together with (ii) using international trade theory-based factors (chosen for a particular region individually) a dominant approach for analyzing trade integration dynamics and its determinants. 
Taking into account heterogeneity of factors affecting international trade and our willingness to focus on the most significant determinants of CEE intraregional trade flows, we decided to narrow down the scope of analysis to three groups of fundamental economic factors affecting trade in Europe, as proposed by Hanousek \& Kočenda (2014) - Figure 1. As extensive queries conducted as part of literature review did not identify similarly both complex and relevant framework, its adequacy can be further justified by three main reasons: (i) the framework's comprehensiveness in reflecting the broad group of determinants, together with it being relatively concise, (ii) its focus on fundamental factors, as opposed to narrow, short-term or cyclical determinants, (iii) the involved factors' significance for Europe, confirmed empirically. In the following paragraphs a brief overview of general theoretical and empirical studies concerning impact of particular groups of factors on trade is presented.

Figure 1. Groups of fundamental factors affecting trade in Europe

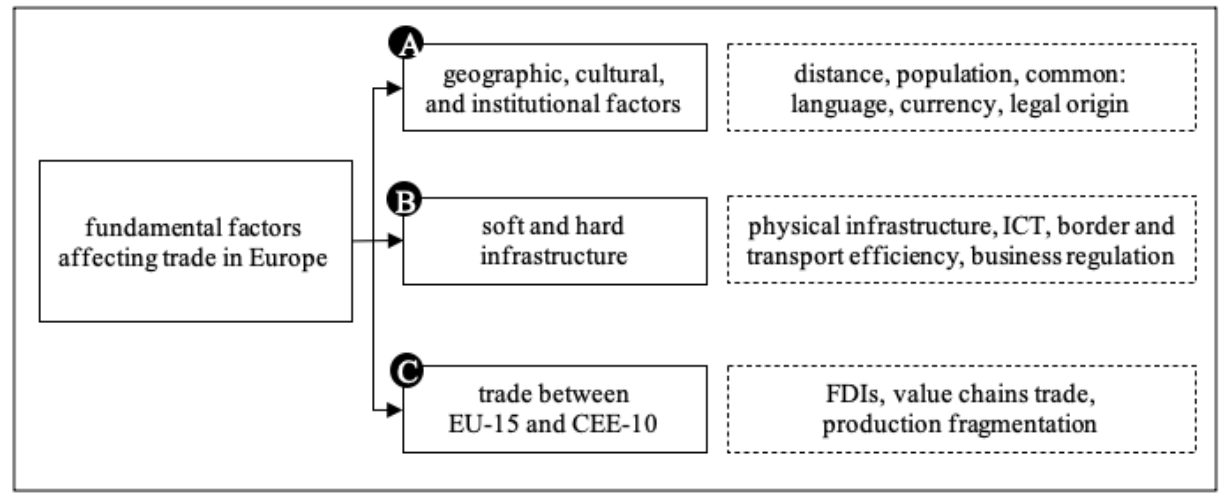

Source: Authors' own elaboration based on Hanousek \& Kočenda (2014).

\subsubsection{Geographic, cultural, and institutional factors}

With influence of institutions ${ }^{4}$ on economic development having been extensively evidenced in literature (Tabellini, 2010), their relationship with international trade flows have been studied more intensively just in the recent years (Beverelli, Keck, Larch, \& Yotov, 2018). As economists agree on a general posi-

4 In this paper, we refer to 'institutions' as a broader term following the approach of WTO (2013, p. 3). This allowed us to include geographic and cultural factors in the scope, as defined by Hanousek \& Kočenda (2014). 
tive influence of national institutions' quality on bilateral trade flows (Francois \& Manchin, 2013) ${ }^{5}$, it is crucial to distinguish between the impacts of (i) political institutions, (ii) economic institutions ${ }^{6}$, and (iii) cultural values (informal institutions), as defined by the World Trade Organization [WTO] (2013). With the impact of strengthening political and economic institutions' quality on international trade found to be strong (Beverelli et al., 2018), its magnitude depends on the scope of institutions and product groups examined (Hanousek \& Kočenda, 2014). Moreover, multiple other studies also pointed to the negative influence of institutional differences between trade partners and their trade-hindering effect (WTO, 2013) - also through the FDI- and VC-channel described later in this section (Baniya, Rocha, \& Ruta, 2019).

As all the countries analyzed in this paper are members of the EU, a vast majority of economic institutions influencing international trade (tax regimes, customs rules etc.) are identical or harmonized (European Commission, 2021) and tariff barriers abolished. Moreover, in light of this, a key role can be played by trade facilitation measures and regulations governing non-tariff barriers to trade (described also in 2.1.2), with such barriers found to still negatively influence trade with the EU Single Market (European Parliament, 2017). Their potential convergence between countries with time could play another factor shaping the CEE trade integration dynamics. As noted by WTO (2013), differences in informal institutions can also negatively affect integration through trade. Taking into account the time period analyzed as part of this piece, significant changes in informal institutions were not likely to occur. ${ }^{7}$ However, their set up in 2004 could influence trade integration dynamics during the analyzed period.

Regarding studies for the CEE region, mixed findings on the influence of institutions on trade were delivered by the literature. In line with WTO (2013), Cheptea (2007) showed that differences between institutions hampered bilateral trade flows among the CEE countries during the accession period. Contrary to that, a potential opposite effect, concerning a later time period, was indicated by

\footnotetext{
5 Although it is not key for this publication purposes, one has to note a two-way relationship between institutions and trade, as evidenced in empirical studies of international trade (WTO, 2013).

6 According to the WTO, economic institutions "determine the functioning and regulation of [...] markets" (WTO, 2013, p. 3) In light of this, trade facilitation measures constitute a linking point between A-B groups of factors. Furthermore, classical trade effects, which could be considered as an institutional factor were described in 2.1.3 - a group of factors that are the most closely linked to the issue.

7 According to the well-known four-layer model by Oliver Williamson, informal institutions tend to change far less often comparing to the duration of the period analyzed as part of this paper.
} 
Gruševaja (2015, p. 6). Based on an empirical study of institutional convergence between CEE-10 and EU-15, she found that the process slowed down after 2004 accession and that multiple CEEs were later "trapped in the regional [institutional] clubs" (Gruševaja, 2015, p. 6).

\subsubsection{Soft and hard infrastructure}

As numerous studies have proved infrastructure to influence trade costs (Francois \& Manchin, 2013), there is an evident impact of its quality on trade. With a general distinction between 'hard' (tangible) and 'soft' (i.e., regulations, institutions) infrastructure, common in the literature, both groups of factors have been empirically shown to exhibit significant impact on trade (Nordås \& Piermartini 2004; Zaki, 2015). Usually placed under the umbrella of 'trade facilitation,' the group of factors relevant for the purpose of this study refers to all measures aimed at reducing trade costs and includes, among others: "quality and traffic-carrying capacity of roads, railways, and (air)ports, the state of telecommunications, and the condition of trade-related institutions, economic regulation, transparency, law, and the business environment" (Hanousek \& Kočenda, 2014, p. 4).

Having noted varying ranges of factors analyzed in empirical studies on the impact of trade facilitation on trade flows, we decided to employ a broader definition of the term. Consequently, we focused on all qualities and measures connected "with the reduction of on-the-border transaction costs other than tariff cuts," as proposed by Portugal-Perez \& Wilson (2012, p. 1). In line with this definition, three studies empirically investigating influence of infrastructure on trade of CEE-10 countries have been found. Damijan, Kostevc, \& Rojec (2015) showed that the quality of both institutions and infrastructure facility have a positive impact on supply capacity of CEE, leading to the higher export of countries from the region to the EU-15. In a study placed at the junction of institutional and infrastructural determinants, Hanousek \& Kočenda (2014) showed that out of the two groups, the second one exerts a relatively higher effect on trade in Europe. Examining relative significance of infrastructural factors, they found that physical infrastructure exerts smaller influence on trade flows than ICT and soft infrastructure (both board and transport efficiency), as well as business regulations. Contrary to that, Bafoil \& Ruiwen (2010) showed that relative significance of soft and hard infrastructure requires further research and that CEE trade has accelerated despite a generally poor transport infrastructure quality of the region. 


\subsubsection{Trade between EU-15 and CEE-10}

As proved by Hanousek \& Kočenda (2014), trade between EU-15 and CEE-10 was an important factor shaping trade landscape in Europe, with foreign direct investment (FDI) as one of the key drivers. In the literature there is mixed evidence on whether trade and FDI are substitutes or complements (Hanzl-Weiss, Leitner, Stehrer, \& Stöllinger 2018). It is mostly due to different effects of inward FDI (IFDI) and outward FDI (OFDI) (Globerman \& Shapiro, 2006), as well as a distinction between vertical FDI (VDFI) that are driven by cost efficiency motivation and lead to production fragmentation on one side and horizontal FDI (HFDI) aimed at seeking new markets on the other (Beugelskdijk, Smeets, \& Zwinkels 2008). Nevertheless, there is unambiguous evidence that FDIs are a major driver of countries' participation in global value chains (GVCs) (Buelens \& Tirpák, 2017), and thus their participation in value chains ${ }^{8}$ (VC) trade (Hanzl-Weiss et al., 2018).

No empirical studies on the impact of FDI and GVCs participation on CEE-10 trade integration have been identified as part of the literature review. As for V4 countries (Czechia, Hungary, Poland, and Slovakia) inward FDIs seem to have no significant effect on regional trade integration (Albulescu \& Goyeau, 2019). However, there is some evidence that FDIs in CEE lead to the higher integration of the region with the EU-15 within GVCs (Cieślik, Biegańska, \& Środa-Murawska, 2016, which could be an important factor shaping trade in CEE-10, in the light of more than $60 \%$ of CEE export taking place within value chains (Chiacchio, Gradeva, \& Lopez-Garcia, 2018). Moreover, there is evidence that FDIs in V4 countries are a significant factor stimulating horizontal and vertical intra-industry trade (Ambroziak, 2011).

In the area of FDI, foreign investments of regional companies, leading to the formation of RVCs could be also indicated as another determinant (Adarov, Astrov, Grieveson, Holzner, \& Hunya, 2019; Iossifov, 2014). However, no empirical studies concerning this area have been identified.

Moreover, as the analyzed time period stretches back from the 2004-2007 accession of the surveyed countries into the UE, significant trade effects (creation and diversion) can be considered as one of the major factors affecting not only CEE-10 trade with the EU-15 (Zaman, 2008), but also the intra-regional trade flows. A hypothesis of a potential trade displacement effect (trade creation between EU-15 and CEE-10, coming at the cost of intra-CEE-10 trade) has been tested by Wilhelmsson (2006) and no such effect has been proved.

\footnotetext{
8 Value chains trade is also known as a supply-chain trade.
} 


\subsection{Literature review on CEE trade integration}

As a result of the conducted literature review, several studies focusing on the CEE trade have been identified - its general trends (Éltető, 2014), external trade with various trade blocs (Damijan et al., 2015; Martínez-Zarzoso, Voicu, \& Vidovic, 2015; Sobański, 2015), and only single pieces aimed at investigating the CEE regional trade integration dynamics (Molendowski, 2012; Moroianu-Dumitrescu \& Novac, 2020).

Multiple other studies examined trade integration between CEE and Euro-Area (Marius-Corneliu, 2013) and trade dynamics between CEE-10 and EU-15, with (Kawecka-Wyrzykowska, 2009; Leitner \& Stehrer, 2014) or without explicitly mentioning trade integration/intensity (Cheptea, 2013; Kang, 2010; Ravishankar \& Stack, 2014). Two of the mentioned publications (Kang, 2010; Kawecka-Wyrzykowska, 2009) had rather narrower scope, referring to intra-industry trade dynamics and/or intensity.

Noting individual studies on regional convergence in CEE, such as Cieślik $\&$ Wciślik (2020), one has to point out to the existence of numerous pieces devoted to the CEE convergence towards EU-15 (Grela et al., 2017). Vastly outnumbering publications referring to CEE - EU-15 trade integration, the enumerated papers do not belong to the scope of the following piece. However, they frequently contain various analyses touching upon the East-West trade nexus in the enlarged EU, thus becoming useful for our study.

Having identified the piece by Moroianu-Dumitrescu \& Novac (2020) as the closest in its scope to the following paper, we would like to point out to a major difference, between the cited piece and this study, identified in the course of the literature review. Although including as many as 12 countries and analyzing trade indicators' dynamics during a period as long as 18 years, the following publication, however, lacks considerations regarding causes of the observed dynamics and a further elaboration on their channels of influence, leading to particular changes in regional trade integration. In conclusion, based on the presented literature review, we identified a research gap concerning the level and dynamics of regional trade integration in CEE and its driving forces.

\section{Research methodology}

According to the prior literature, measuring regional trade integration could follow two approaches. The first method concentrates on prerequisites for integration (usually by measuring a degree of trade liberalization between analyzed 
countries), whereas the other one focuses on trade outcomes, by measuring trade volumes (Brahmbhatt, 1998). With the EU being an economic union and thus measuring trade liberalization becoming irrelevant (Martínez-San Román, Bengoa, \& Sánchez-Robles, 2016), we chose to employ the second approach. To comprehensively assess the CEE trade integration, we applied several literaturebased indicators, drawing from Iapadre \& Plummer (2011).

On a country-to-CEE-9 level we calculated intra-regional trade share $\left(S_{i}\right)$ in total trade (Iapadre \& Plummer, 2011). The indicator shows the share of country's trade with the CEE region in country's total international trade (where $i$ is a CEE country and $T$ symbolizes this country's total trade which is calculated as exports $(X)$ plus imports $(M)$ with region and total exports and import with the world, including the region $)^{9}$ :

$$
S_{i}=\frac{T_{i}^{C E E}}{T_{i}^{\text {World }}}=\frac{X_{i}^{C E E}+M_{i}^{C E E}}{X_{i}^{\text {World }}+M_{i}^{\text {World }}}
$$

As the definition shows, higher value of trade share implies a higher level of country's trade integration with the region. To investigate the driving forces of the indicator's value, we decomposed it by calculating trade share in exports (similarly to Bandara \& Yu (2003)) and in imports, using the formulas 2 and 3.

$$
\begin{gathered}
S_{\text {export } i}=\frac{X_{i}^{C E E}}{X_{i}^{\text {World }}} \\
S_{\text {import } i}=\frac{M_{i}^{\text {CEE }}}{M_{i}^{\text {World }}}
\end{gathered}
$$

Both indicators show a share of CEE country's export (import) directed to (originating from) the other CEE-9 countries.

Using the obtained results, we then calculated trade shares for total trade, for exports and for imports on the regional (CEE-10) level. ${ }^{10}$ To account for the bias involved (resulting from differences in the scale of trade exchange with CEE-9 between particular countries), intra-regional trade share $\left(S_{C E E}\right)$ was also calculated (a weighted average of $S_{i}$ ) according to the formula 4 .

\footnotetext{
9 The described indicator is also known as 'intra-regional trade integration' (Mongelli, Dorucci, \& Agur, 2005).

${ }^{10}$ Indicators on the regional level for particular trade flows were calculated as unweighted averages of trade shares on a country-level, described above.
} 


$$
S_{C E E}=\frac{T_{C E E}^{C E E}}{T_{C E E}^{W} \text { orld }}
$$

Despite being positively affected by the number of countries in the sample as well by size of the region in terms of total trade and having pro-cyclical bias, trade share indicators have intuitive appeal and are widely used in the empirical analysis of regional trade integration (Iapadre \& Plummer, 2011).

Finally, to relate the pace of regional trade integration to the global trade dynamics, intra-regional trade intensity index $\left(I_{C E E}\right)$, was also added to the scope (Formula 5). The described indicator compares share of intraregional trade in the region's trade to the world with the region's share in global trade. If the index is equal to 1 , it means that the intraregional trade is neutral, when it is lower/higher than 1 , the region has a negative/positive bias towards itself (Iapadre \& Plummer, 2011).

$$
I_{C E E}=\frac{T_{C E E}^{C E E} / T_{C E E}^{\text {World }}}{T_{C E E}^{\text {World }} / T_{\text {World }}^{\text {World }}}
$$

According to Iapadre \& Plummer (2011), the index may display significant biases, while used to make comparisons between regions. As such an application of the indicator is not involved in this paper, we decided not to employ further (more standardized indices ${ }^{11}$ ), as recommended by the authors (Iapadre \& Plummer, 2011, pp. 106-107).

Data in the paper were collected from United Nations Conference on Trade and Development [UNCTAD] (2020) database. In line with WTO recommendations, importer-reported data were chosen as more conservative, thus more reliable for analyses.

\section{Research findings}

As Figure 2 shows, an advancing CEE-10 regional trade integration could be observed between 2004 and 2018. Apart from being not monotonic, it exhibited the fastest dynamics immediately after the accession - with its pace decreasing in time, since the period of the Global Financial Crisis. With both weighted and unweighted trade shares by around 5 pp., the former value (approaching almost $18 \%$ in 2018) indicates that intra-regional trade constituted almost onefifth of the CEE-10 trade exchange in goods (import and export, collectively). For all the analyzed years, values of the unweighted indicator remained higher,

\footnotetext{
${ }^{11}$ For example the regional trade introversion index (Iapadre \& Plummer, 2011, pp. 107-110).
} 
because of a relatively bigger trade share displayed by countries with the smallest volumes of trade exchange among CEE-10. For example, three countries with the lowest trade volume with the world in 2004 (Latvia, Estonia, and Lithuania) have their unweighted trade share average at the level of $19.3 \%$, ca. 5.7 pp. above the unweighted average for the whole region. The same group of three Baltic states recorded the lowest trade volume in 2018, when their average of trade share amounting to $28.0 \%$, ca. 10.2 pp. above the region's unweighted trade share. Nevertheless, three countries with the highest trade volume with the world (Poland, Czechia, and Hungary) have unweighted trade share average on the level of $12.6 \%$ and $16.6 \%$ in 2004 and 2018, respectively, which is significantly lower than the respective values for the region. A steadily growing gap observed in Figure 2, which more than doubled during the analyzed timeframe, seems to have resulted from a relatively faster integration of smaller countries (in terms of trade volume) reaching higher trade share growth. ${ }^{12}$

Figure 2. Intra-regional trade shares for trade volume (export and import) for the CEE region in the period 2004-2018

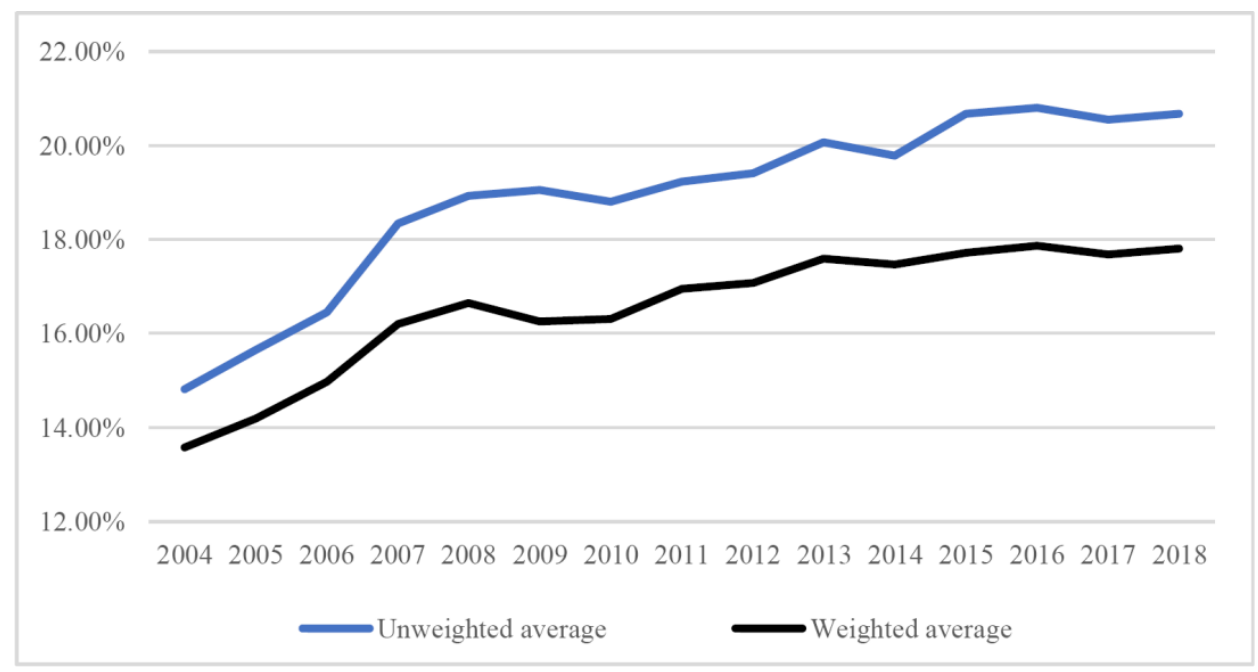

Source: Authors' own elaboration based on UNCTAD data (2020).

${ }^{12}$ Although referred to as regional integration steaming from tightening trade relation within the region, it is worth to note that it could also be driven by a lagging country's trade exchange dynamics in global terms with a maintained nominal trade dynamic with the region (Table 3 in Appendix). 
Although growing in the recent years and not low (in absolute terms), trade shares (both weighted and unweighted) of CEE-10 are relatively low, when compared with analogous indicator's values for the whole EU (30.3\% in 2018), implying weaker CEE regional integration than on the EU level. When put into broader perspective, it takes values similar to USMECA (19.1\%), and is significantly higher in comparison with other chosen trade blocs, including: ASEAN (10.5\%), EAEU (7.1\%), MERCOSUR (6.7\%) and AU (5.7\%) (Kofner, 2020) ${ }^{13}$ with three out of four of the enumerated blocs exhibiting a growing level of regional trade integration in the 2007-2018 period (similarly to the dynamics observed for the CEE region).

Figure 3. Intra-regional trade shares in export and import for the CEE region in the period 2004-2018

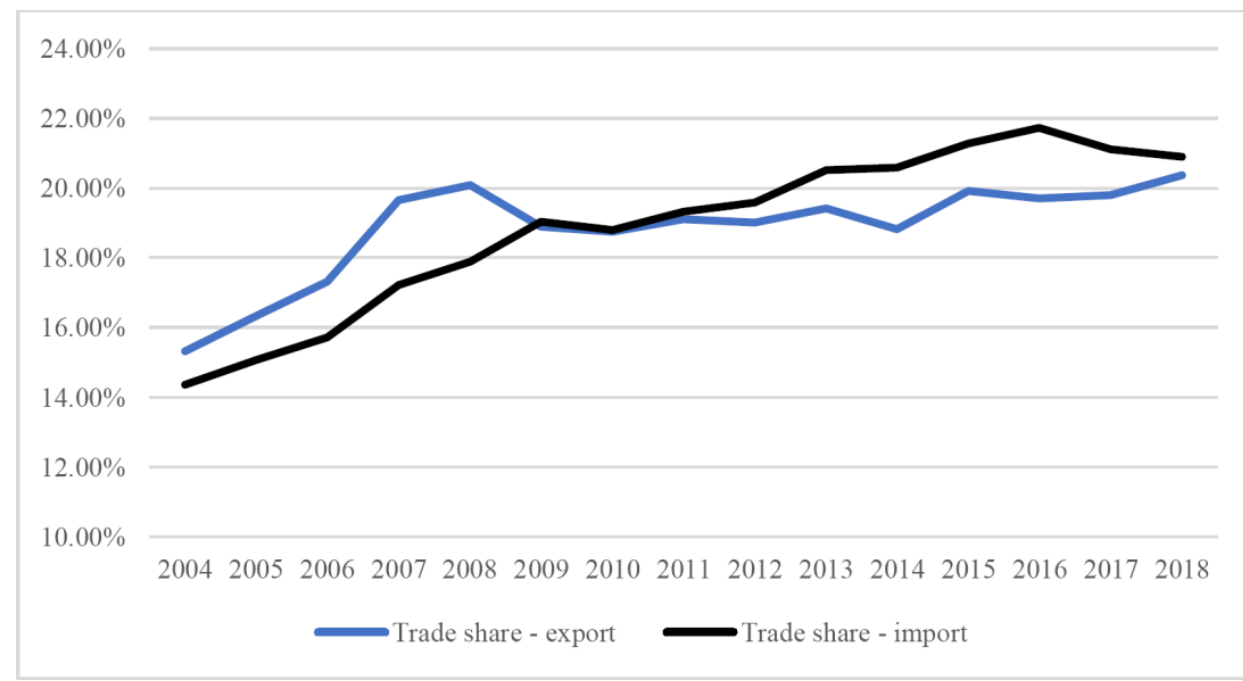

Source: Authors' own elaboration based on UNCTAD data (2020).

The unweighted indicator's decomposition into export and import trade share has been presented in Figure 3. According to the most recent values, import from CEE-9 constituted on average around 20.9\% of CEE-10 import structure, whereas the equivalent figure for export amounted to $20.4 \%$. With both indicators' dynamics reflecting advancing trade integration of the region, a rela-

${ }^{13}$ The full names of given blocks are: USMECA - United States - Mexico - Canada free trade agreement (former NAFTA), ASEAN - Association of Southeast Asian Nations, EAEU - Eurasian Economic Union, MERCOSUR - South American Common Market, AU - African Union. 
tively faster growth of import trade share (leading to a single intersection point between the two indicators) can be observed in Figure 3. It can be understood as a consequence of a faster growth of CEE-10 countries' export to the world comparing with region's import, leading to a lower trade deficit in relative terms (with the nominal one rising slightly during the analyzed period).

Figure 4. Intra-regional trade intensity index for the CEE region in the period 2004-2018

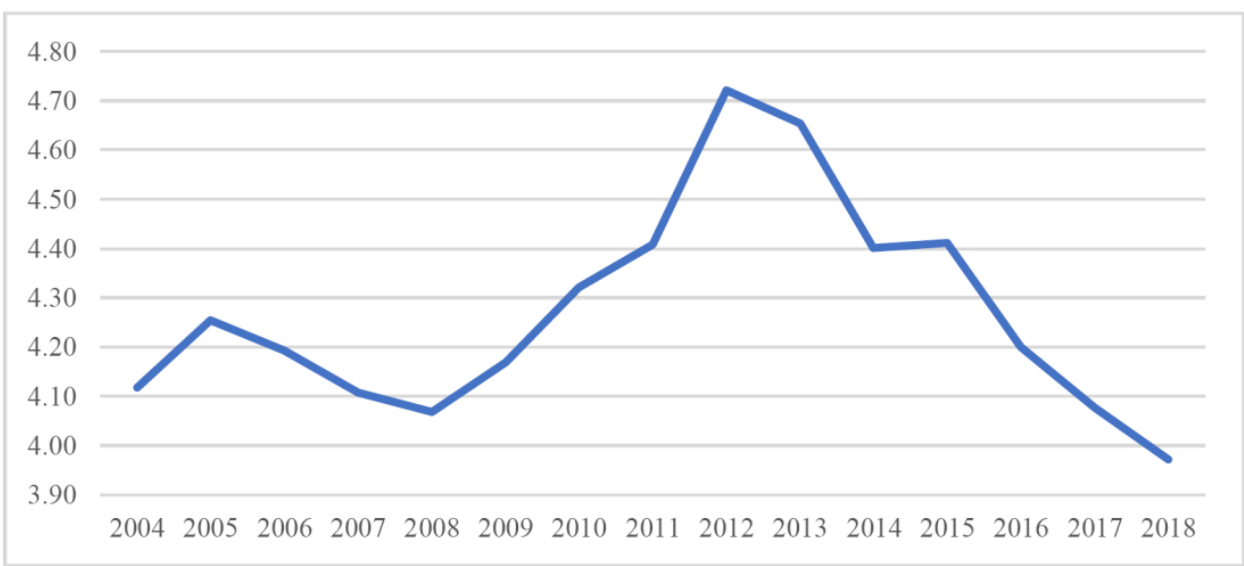

Source: Authors' own elaboration based on UNCTAD data (2020).

A significantly different assessment of the CEE-10 regional trade integration dynamics could be made based on another common indicator - intra-regional trade intensity index. According to the data displayed in Figure 4, its value fluctuated through the whole analyzed period, displaying a countercyclical nature. Starting from around 4.1 and having achieved its peak of roughly 4.7 as a result of 2008-2012 dynamics, it was experiencing an almost constant and rapid decline, leading to a value of less than 4.0 in 2018 . With the described indicator's value well above 1.0 (reflecting the region's high level of trade integration), its decrease signals relative CEE-10 trade disintegration (in the sense of trade share dynamics lagging behind the CEE-10 contribution to the global trade) in the 2004-2018 time period. Such dynamics can be interpreted as the effect of the global trade growth outpacing the regional trade integration. One has to note, however, a potential impact of macroeconomic factors on anticyclical changes of the above index, together with its susceptibility to the choice of the time period under analysis. 
Table 1. Country to CEE intra-regional trade shares in selected years, compound annual growth rate (CAGR) for trade shares, and trade balance with CEE-9 as a $\%$ of export to $\mathrm{CEE}$

\begin{tabular}{|c|c|c|c|c|c|c|c|}
\hline \multirow[t]{2}{*}{ Country } & \multicolumn{4}{|c|}{ Trade share $(\%)$} & \multirow{2}{*}{$\begin{array}{c}\text { Trade share } \\
\text { CAGR } \\
2004-2018 \\
\end{array}$} & \multicolumn{2}{|c|}{$\begin{array}{l}\text { Trade balance with CEE-9 } \\
\text { (as a \% of export to CEE) }\end{array}$} \\
\hline & 2004 & 2007 & 2013 & 2018 & & 2004 & 2018 \\
\hline Bulgaria & $8.4 \%$ & $11.0 \%$ & $14.8 \%$ & $17.4 \%$ & $5.34 \%$ & $-66.7 \%$ & $-30.5 \%$ \\
\hline Czechia & $15.5 \%$ & $16.3 \%$ & $17.3 \%$ & $17.2 \%$ & $0.73 \%$ & $15.9 \%$ & $-5.9 \%$ \\
\hline Estonia & $14.7 \%$ & $20.4 \%$ & $21.3 \%$ & $22.9 \%$ & $3.23 \%$ & $-13.2 \%$ & $-30.0 \%$ \\
\hline Hungary & $11.1 \%$ & $16.1 \%$ & $19.2 \%$ & $19.8 \%$ & $4.21 \%$ & $-6.4 \%$ & $-7.1 \%$ \\
\hline Latvia & $23.5 \%$ & $31.1 \%$ & $38.0 \%$ & $35.2 \%$ & $2.92 \%$ & $-96.2 \%$ & $-47.5 \%$ \\
\hline Lithuania & $19.7 \%$ & $25.5 \%$ & $23.3 \%$ & $25.8 \%$ & $1.95 \%$ & $-15.2 \%$ & $-21.9 \%$ \\
\hline Poland & $11.1 \%$ & $12.4 \%$ & $12.6 \%$ & $12.9 \%$ & $1.10 \%$ & $13.0 \%$ & $37.3 \%$ \\
\hline Romania & $9.9 \%$ & $15.5 \%$ & $18.2 \%$ & $18.9 \%$ & $4.75 \%$ & $-53.4 \%$ & $-63.4 \%$ \\
\hline Slovakia & $23.7 \%$ & $23.6 \%$ & $24.9 \%$ & $24.7 \%$ & $0.28 \%$ & $6.3 \%$ & $8.8 \%$ \\
\hline Slovenia & $10.6 \%$ & $11.6 \%$ & $11.2 \%$ & $12.0 \%$ & $0.91 \%$ & $9.9 \%$ & $19.4 \%$ \\
\hline $\begin{array}{l}\text { CEE average } \\
\text { (unweighted) }\end{array}$ & $14.8 \%$ & $18.3 \%$ & $20.1 \%$ & $20.7 \%$ & - & - & - \\
\hline
\end{tabular}

Source: Authors' own elaboration based on UNCTAD data (2020).

Trade share values on a country-level ${ }^{14}$ have been presented in Table 1, together with the trade balance of each country with CEE-9 (as a share of total country's export to CEE). As all the countries were integrating within CEE between 2004 and 2018 (higher trade share), the dynamics of the described integration (CAGR 2004-2018) varied much across CEE, with Romania and Bulgaria (countries that joined the EU in 2007) as clear leaders. On the other end of the spectrum, there were Slovakia, Czechia and Slovenia - all of them reaching the average annual rate of trade share growth below $1.0 \%$. Moreover, Czechia was the only country disintegrating with CEE-9 in terms of decomposed (exports, imports) trade share dynamics - with the country's export trade share going down during the analyzed period (Table 4 and 5 in Appendix).

With Slovakia and Latvia as the most integrated countries (trade share exceeding $20 \%$ at the time) in 2004, only Latvia managed to maintain this result until 2018 and became a CEE leader of regional integration, exceeding the second country (Lithuania) by as much as almost $10 \mathrm{pp}$. Another visible pattern is growing regional discrepancies, with a gap between the three most and the three least integrated countries growing slightly from $12.7 \%$ to $14.5 \%$ during the ana-

\footnotetext{
${ }^{14}$ The following data refer to the share of a country's trade exchange with CEE-9 in the total country's trade exchange and constituted a basis for calculating the unweighted trade share for the whole region, displayed in Figure 2 as a blue line.
} 
lyzed period. It is also worth noting that countries recording permanent surpluses with CEE-9 (Poland, Slovakia, and Slovenia) all exhibit relatively low regional integration dynamics ( 2 out of 3 laggards of integration, all with CAGR $<1.5 \%$ ), whereas those with a trade deficit achieved CAGR of more than $1.5 \%$ during the analyzed timeframe.

Table 2. Country to country compound annual growth rates of export and import in the period of 2004-2018 (\%)

\begin{tabular}{|c|c|c|c|c|c|c|c|c|c|c|c|}
\hline & \multicolumn{10}{|c|}{ Exporting country } \\
\hline & & $\mathrm{BG}$ & $\mathrm{CZ}$ & $\mathrm{EE}$ & $\mathrm{HU}$ & LV & LT & $\mathrm{PL}$ & RO & SK & SI \\
\hline \multirow{10}{*}{ 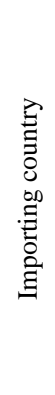 } & BG & & 9.8 & 18.4 & 15.4 & 21.9 & 14.1 & 13.5 & 13.9 & 11.1 & 8.2 \\
\hline & $\mathrm{CZ}$ & 17.0 & & 11.2 & 8.6 & 15.2 & 15.9 & 11.1 & 18.9 & 7.0 & 6.1 \\
\hline & $\mathrm{EE}$ & 10.5 & 9.1 & & 0.5 & 10.6 & 8.7 & 10.6 & 19.2 & 12.8 & 11.7 \\
\hline & $\mathrm{HU}$ & 12.5 & 9.2 & -3.8 & & 12.7 & 10.8 & 9.3 & 9.6 & 11.9 & 10.1 \\
\hline & $\mathrm{LV}$ & 11.6 & 6.3 & 8.6 & 8.2 & & 9.8 & 11.0 & 17.0 & 7.7 & 8.2 \\
\hline & LT & 11.8 & 9.4 & 7.6 & 7.9 & 13.0 & & 11.2 & 21.1 & 11.1 & 9.3 \\
\hline & PL & 13.4 & 7.8 & 10.6 & 7.0 & 9.3 & 11.5 & & 13.6 & 8.8 & 5.5 \\
\hline & $\mathrm{RO}$ & 15.8 & 10.5 & 26.8 & 14.3 & 18.4 & 16.6 & 14.4 & & 14.5 & 11.6 \\
\hline & SK & 16.0 & 6.5 & 14.0 & 11.3 & 11.5 & 13.3 & 11.1 & 17.2 & & 4.4 \\
\hline & SI & 11.4 & 5.8 & 12.0 & 4.0 & 9.0 & 17.6 & 9.8 & 11.1 & 6.2 & \\
\hline
\end{tabular}

Legend: Values less than 0 are marked in red, values in the range $\langle 0-10\rangle$ in black, $(10 ; 20\rangle$ in blue and $\rangle 20$ in green.

Source: Authors' own elaboration based on UNCTAD data (2020).

As Table 2 shows, the advancing integration evidenced above was fueled by a growing volumes of trade exchange between all the analyzed countries, rather than merely some of the region's subblocks. As presented in Table 2, export and import grew on a country-to-country level for all CEE-10, with just one exception (export from Estonia to Hungary). With its highest pace exceeding an annual average of $20 \%$ in some cases (trade doubling at least every 4 years), the respective trade dynamics could be considered as hyper-integration. However, an adequate interpretation of the observed dynamics requires taking into account the three following remarks that are discussed in more detail in the following paragraph: (i) very low starting trade volumes in chosen exporter-importer pairs, (ii) a significant variation in the dynamics in time - not reflected in CAGR, (iii) a necessity to refer CAGR values to the pace of global and regional trade growth (Table 3).

First, as Tables 6 and 7 show (Appendix) the starting point data included multiple exporter-importer pairs with trade volumes lower than USD 100 million, thus implying that the observed 2004-2018 growth (described by CAGR) 
took low values in absolute terms. Moreover, in the case of 11 such pairs trade volumes were extremely low, not exceeding as little as USD 10 million, making such dynamics of relations susceptible to export/import decisions made by single companies. Further analysis on the product groups' composition underlying particular trade flows may prove useful in that regard. Second, based on a closer examination of the observed country-to-country trade dynamics, one has to point out to the existence of negative year-to-year trade volume growth rates in multiple exporter-importer pairs (the most frequently as an aftermath of the Global Financial Crisis in 2008-2009, and between 2014-2015), ${ }^{15}$ as well as to the values of year-on-year growth rates being systematically higher immediately after accession (with classical trade creation effects among potential causes). Finally, one has to note a broader context of the observed dynamics relative to the global trade growth. With the latter value rising annually by around 5.4\% (on average) during the analyzed time period, ${ }^{16}$ only higher CAGR values can be considered as indicators of real trade integration. Moreover, $8.3 \%$ annual growth of intra-regional trade (on average) might serve as another useful benchmark that allows the identification of genuine leaders of trade integration (those with multiple CAGRs $>8.3 \%$ and multiple starting point trade volumes of a significant value).

\section{Discussion}

General finding of the paper that the CEE trade integration has strengthened after the accession of the countries from the region to the EU, confirms the results of study by Moroianu-Dumitrescu \& Novac (2020). Similar results for the first years after the accession were also obtained by Molendowski (2012).

This study found several patterns which could shed a light on a potential determinants of CEE regional trade integration dynamics. First, smaller countries in terms of trade volume have higher levels of integration than large countries. As Iapadre \& Plummer (2011) note, such patterns are consistent with findings for other regions, thus they are not CEE-specific. Second, countries with lower share of intraregional trade at the beginning of the analyzed period exhibit higher dynamics of integration, especially Bulgaria and Romania, which could be attributed to the later accession of these two countries to the EU (and partly due to the base effect). Third, wealthiest or more capital-intensive countries (espe-

\footnotetext{
${ }^{15}$ Some cases of single negative year-to-year growth rates could also be attributed to the USD denomination of trade flows reported in the countries' domestic currencies.

${ }^{16}$ According to the WTO data (data.wto.org) on Merchandise imports (Total merchandise).
} 
cially Slovenia, Czechia, and Slovakia which are among four countries with the highest GDP per capita in the region ${ }^{17}$ ) exhibit lower growth rates of intraregional trade. Fourth, in the analyzed period, countries exhibiting permanent deficits in trade with the region tend to have higher integration growth rates than countries with permanent surpluses (Poland, Slovakia, Slovenia). Finally, one has to point out to the fact that trade integration dynamics was the fastest immediately after accession and slowed down later. This pattern is visible both on regional- and country-level, which suggests that post-accession trade effects were a major, common pro-integration factor for CEE-10.

As evidenced by Cheptea (2007), differences in national institutions hampered trade flows in CEE - even despite the ongoing convergence toward the EU norms. According to Gruševaja (2015), the latter process slowed down after the 2004 accession, which suggests that its contribution to the initial high pace of integration was minor. Similar conclusion can be drawn for the later time period, as countries constituting the institutional clubs distinguished by the author did not exhibit above-average bilateral trade dynamics. Regarding geographical factors, the analyzed data revealed a visible pattern of slower integration in the case of countries located closer to the EU-15 (Czechia, Poland, Slovakia, Slovenia). As they are poised to be more integrated with neighboring EU-15 countries (Germany, Austria, Italy), the geographical distance from the EU-15 might have played a role in determining the pace of CEE country's trade integration with CEE-9. Such a pattern is consistent also in case of peripheral Baltic states, displaying significant levels of trade integration dynamics. Apart from displaying a lower potential for integration with enumerated EU-15s, they joined the EU during an ongoing process of shifting their trade structure from Russia to other regions - including CEE (Laaser \& Schrader, 2002). It suggests that regional trade integration dynamics was heavily impacted by countries located further from EU-15. As for informal institutions, a pattern of high starting-point trade volume and a relatively low trade integration dynamics between countries with significant linguistic proximity and common history (i.e., Czechia and Slovakia, Latvia and Lithuania) or tight political cooperation (i.e., V4) has been identified in the analyzed data.

The analyzed data does not reveal relevant country-level patterns regarding a potential impact of hard infrastructure. As hard infrastructure was only a minor contributor to CEE trade during the accession period, the most significant im-

${ }^{17}$ With almost 26.1, 23.4 and 19.3 thousand USD (current prices) in 2018, respectively (World Bank, 2020). 
provements of its quality took place in countries less developed in that regard (Bafoil \& Ruiwen, 2010). Similar pattern, of less capital-intensive countries improving faster, could be observed for years 2007-2018 (World Bank, 2020. An informal look at Logistics Performance Index (LPI), reveals that no developments in line with trade integration dynamics were displayed by particular countries (or groups thereof).

Results of the study showed that countries of the region exhibited permanent surpluses/deficits in trade with the region during the analyzed period. As surpluses concerned Poland, Slovakia and Slovenia, the pattern could be partly attributed to the higher level of overall competitiveness of these economies (Daszkiewicz \& Olczyk, 2014). Other possible explanation may also refer to the formation of RVCs by the enumerated countries (Gereffi, 2013), as well as directions of trade flows within GVCs located in the region. There is evidence that participation of CEE countries in GVCs has been growing, with declining domestic value added (DVA) as an effect (Olczyk \& Kordalska, 2017). Other studies by Cieślik, Biegańska, \& Środa-Murawska (2019) showed that in 2014, share of foreign value added (FVA) in gross exports of some of CEE-10s was significant. For example, contribution from Poland in gross export of Czechia, Estonia and Lithuania was higher than $6 \%$, which was the second or third highest. ${ }^{18} \mathrm{In}$ the case of Slovakia, its contribution to Czechian and Hungarian export was at a substantial level (Cieślik et al., 2019). This suggests that participation in GVCs could have positive influence on trade balance of countries that note surpluses, however, it requires further in-depth research based on input-output databases. Moreover, there is a question of general influence of participation in GVCs on trade integration of CEE countries.

Lastly, one has to refer the pattern of integration dynamics slowing down systematically to classical trade effects. While fading with time, they played a significant role during early post-accession years. As Wilhelmsson (2006) evidenced for the pre-accession period, trade creation occurred not only between CEE-10 and EU-15, but also inside the region. As the pattern is relevant for the region as a whole and multiple countries at the same time, it seems to be the most evident determinant of trade integration dynamics visible in the analyzed data.

${ }^{18}$ In Lithuania is even higher than the share of FVA from Germany. 


\section{Conclusions}

As the analyzed data reveal, CEE regional trade integration has been on the rise for 15 years following the 2004 accession, with both weighted and unweighted trade shares rising by approximately $5 \mathrm{pp}$. (reaching $20.67 \%$ at the end of the analyzed period in the case of the latter). A significantly faster growth could be observed during several years of the post-accession period, until the outbreak of the Global Financial Crisis (2008-09). A comparison of the obtained figures with values of analogous indicators for other regions, shows that $\mathrm{CEE}$ displays a relatively high level of regional trade integration, although considerably lower than the EU as a whole (ca. 10 pp.). Trade intensity indicated a significant level of such integration among CEE-10, by fluctuating around the value of 4 , and thus implying a four times stronger regional integration than its potential level, based on the region's share in global trade.

Conducted empirical work has revealed several CEE- and country-level integration patterns - referring to the country size (trade volume), trade balance with CEE-9 and the pace of integration in time. Early post-accession trade effects seemed to be the only evident (and common for all countries) factor driving dynamics of regional trade integration. As their impact and the pace of integration faded with time, a future engine of the integration process remains an open question. According to the conducted literature review, formation of RVCs by companies from the region might play a role in this regard. Reshoring of manufacturing, possibly triggered by the COVID-19 pandemic, could also lead to increased participation of CEE-10s in GVCs. However, their impact on regional trade integration would be rather ambiguous.

Main contributions of this study are conclusions from a holistic analysis of CEE trade integration based on multiple literature-based indicators and a discussion of region- and country-level patterns in the analyzed data. To the best of our knowledge, a similar study with described features has not yet been published. Limitations of this study include lack of product-groups-level trade data, missing values of trade volumes for 2019 and 2020 and a narrow scope of examined trade flows (in goods only). The study brings two main implications for other researchers. First, the CEE trade integration dynamics is a topic relatively unexplored in the literature, in need of further research. Second, the CEE trade integration determinants are analyzed by the literature in a fragmented way and require additional comprehensive research (possibly by means of econometric methods). 


\section{Acknowledgements}

Authors would like to express their gratitude to Professor Adam A. Ambroziak, Ph.D. and Professor Krzysztof Falkowski, Ph.D. from SGH Warsaw School of Economics for their help and substantial support with the early version of this paper. We would also like to thank two anonymous reviewers for their valuable remarks and comments.

\section{Appendix}

Table 3. Country to CEE computed annual growth rate of: trade share, volume of intra-regional and volume of trade with the world (export + import)

\begin{tabular}{|l|r|r|r|}
\hline \multirow{2}{*}{ Country } & \multicolumn{3}{|c|}{ CAGR (2004-2018) for trade volume (export + import) } \\
\cline { 2 - 4 } & Trade share $\left(\mathrm{S}_{\mathrm{i}}\right)$ & Intra-regional trade & \multicolumn{1}{c|}{ Trade with the world } \\
\hline Bulgaria & $5.34 \%$ & $13.71 \%$ & $7.95 \%$ \\
\hline Czechia & $0.73 \%$ & $8.71 \%$ & $7.93 \%$ \\
\hline Estonia & $3.23 \%$ & $8.98 \%$ & $5.57 \%$ \\
\hline Hungary & $4.21 \%$ & $9.91 \%$ & $5.47 \%$ \\
\hline Latvia & $2.92 \%$ & $10.38 \%$ & $7.25 \%$ \\
\hline Lithuania & $1.95 \%$ & $10.67 \%$ & $8.54 \%$ \\
\hline Poland & $1.10 \%$ & $10.07 \%$ & $8.87 \%$ \\
\hline Romania & $4.75 \%$ & $13.62 \%$ & $8.47 \%$ \\
\hline Slovakia & $0.28 \%$ & $8.89 \%$ & $8.58 \%$ \\
\hline Slovenia & $0.91 \%$ & $7.42 \%$ & $6.45 \%$ \\
\hline
\end{tabular}

Source: Authors' own elaboration based on UNCTAD data (2020).

Table 4. Country to CEE intra-regional trade share in import for selected years and computed annual growth rate for trade share in the period 2004-2018

\begin{tabular}{|l|r|r|r|r|r|}
\hline \multirow{2}{*}{ Country } & \multicolumn{4}{|c|}{ Trade share $(\%)$} & \multicolumn{1}{c|}{ Trade share CAGR } \\
\cline { 2 - 6 } & \multicolumn{1}{|c|}{2004} & 2007 & \multicolumn{1}{c|}{2013} & \multicolumn{1}{c|}{2018} & $2004-2018$ \\
\hline Bulgaria & $8.8 \%$ & $11.1 \%$ & $16.8 \%$ & $18.4 \%$ & $5.40 \%$ \\
\hline Czechia & $13.4 \%$ & $15.2 \%$ & $17.6 \%$ & $17.6 \%$ & $1.94 \%$ \\
\hline Estonia & $13.9 \%$ & $19.3 \%$ & $24.4 \%$ & $24.1 \%$ & $4.00 \%$ \\
\hline Hungary & $10.7 \%$ & $14.0 \%$ & $19.3 \%$ & $20.7 \%$ & $4.81 \%$ \\
\hline Latvia & $27.5 \%$ & $32.9 \%$ & $42.4 \%$ & $38.7 \%$ & $2.47 \%$ \\
\hline Lithuania & $17.9 \%$ & $23.2 \%$ & $22.0 \%$ & $25.8 \%$ & $2.63 \%$ \\
\hline Poland & $9.1 \%$ & $9.3 \%$ & $9.4 \%$ & $9.5 \%$ & $0.31 \%$ \\
\hline Romania & $10.5 \%$ & $16.3 \%$ & $21.2 \%$ & $21.5 \%$ & $5.24 \%$ \\
\hline Slovakia & $22.4 \%$ & $21.2 \%$ & $22.4 \%$ & $22.9 \%$ & $0.17 \%$ \\
\hline Slovenia & $9.3 \%$ & $9.5 \%$ & $9.6 \%$ & $10.0 \%$ & $0.46 \%$ \\
\hline CEE (average) & $14.4 \%$ & $17.2 \%$ & $20.5 \%$ & $20.9 \%$ & - \\
\hline
\end{tabular}

Source: Authors' own elaboration based on UNCTAD data (2020). 
Table 5. Country to CEE intra-regional trade share in export for selected years and computed annual growth rate for trade share in the period 2004-2018

\begin{tabular}{|l|r|c|r|r|r|}
\hline \multirow{2}{*}{ Country } & \multicolumn{4}{|c|}{ Trade share (\%) } & \multicolumn{1}{c|}{ Trade share CAGR } \\
\cline { 2 - 6 } & \multicolumn{1}{|c|}{2004} & 2007 & 2013 & 2018 & \multicolumn{1}{c|}{$2004-2018$} \\
\hline Bulgaria & $7.8 \%$ & $10.7 \%$ & $12.5 \%$ & $16.3 \%$ & $5.38 \%$ \\
\hline Czechia & $17.9 \%$ & $17.4 \%$ & $16.9 \%$ & $16.8 \%$ & $-0.45 \%$ \\
\hline Estonia & $15.6 \%$ & $22.3 \%$ & $17.4 \%$ & $21.5 \%$ & $2.30 \%$ \\
\hline Hungary & $11.5 \%$ & $18.4 \%$ & $19.1 \%$ & $18.9 \%$ & $3.57 \%$ \\
\hline Latvia & $18.4 \%$ & $28.3 \%$ & $32.2 \%$ & $31.1 \%$ & $3.83 \%$ \\
\hline Lithuania & $22.1 \%$ & $29.1 \%$ & $24.9 \%$ & $25.7 \%$ & $1.10 \%$ \\
\hline Poland & $13.7 \%$ & $16.4 \%$ & $16.1 \%$ & $16.7 \%$ & $1.43 \%$ \\
\hline Romania & $9.0 \%$ & $13.9 \%$ & $14.7 \%$ & $15.8 \%$ & $4.09 \%$ \\
\hline Slovakia & $25.2 \%$ & $26.2 \%$ & $27.6 \%$ & $26.6 \%$ & $0.39 \%$ \\
\hline Slovenia & $12.0 \%$ & $14.0 \%$ & $12.9 \%$ & $14.4 \%$ & $1.30 \%$ \\
\hline CEE (unweighted average) & $15.3 \%$ & $19.7 \%$ & $19.4 \%$ & $20.4 \%$ & - \\
\hline
\end{tabular}

Source: Authors' own elaboration based on UNCTAD data (2020).

Table 6. Country to country trade exchange matrix, 2004 (in USD, millions)

\begin{tabular}{|c|c|c|c|c|c|c|c|c|c|c|c|}
\hline & \multicolumn{10}{|c|}{ Exporting country } \\
\hline & & BG & $\mathrm{CZ}$ & EE & $\mathrm{HU}$ & LV & LT & PL & RO & SK & SI \\
\hline \multirow{10}{*}{ 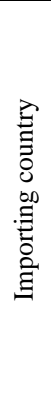 } & BG & & 244 & 3 & 176 & 3 & 12 & 215 & 422 & 106 & 92 \\
\hline & $\mathrm{CZ}$ & 88 & & 28 & 1397 & 18 & 47 & 3219 & 221 & 3573 & 359 \\
\hline & $\mathrm{EE}$ & 6 & 92 & & 106 & 318 & 444 & 257 & 6 & 20 & 11 \\
\hline & $\mathrm{HU}$ & 91 & 1724 & 87 & & 16 & 45 & 1944 & 902 & 1205 & 458 \\
\hline & LV & 10 & 105 & 501 & 63 & & 872 & 384 & 4 & 59 & 13 \\
\hline & LT & 19 & 190 & 399 & 100 & 475 & & 947 & 7 & 46 & 37 \\
\hline & PL & 131 & 3188 & 81 & 1664 & 178 & 476 & & 406 & 1453 & 459 \\
\hline & RO & 349 & 707 & 5 & 1034 & 3 & 14 & 822 & & 335 & 166 \\
\hline & SK & 34 & 3980 & 6 & 998 & 10 & 14 & 1169 & 146 & & 229 \\
\hline & SI & 36 & 419 & 3 & 543 & 5 & 4 & 276 & 126 & 232 & \\
\hline
\end{tabular}

Source: Authors' own elaboration based on UNCTAD data (2020).

Table 7. Country to country trade exchange matrix, 2018 (in USD, millions)

\begin{tabular}{|c|c|c|c|c|c|c|c|c|c|c|c|}
\hline & \multicolumn{10}{|c|}{ Exporting country } \\
\hline & & BG & $\mathrm{CZ}$ & EE & $\mathrm{HU}$ & $\mathrm{LV}$ & LT & PL & RO & SK & SI \\
\hline \multirow{10}{*}{ 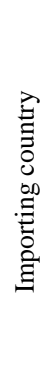 } & $\mathrm{BG}$ & & 902 & 29 & 1310 & 40 & 78 & 1262 & 2603 & 465 & 279 \\
\hline & $\mathrm{CZ}$ & 793 & & 124 & 4423 & 130 & 374 & 14135 & 2494 & 9174 & 819 \\
\hline & EE & 26 & 311 & & 114 & 1308 & 1426 & 1055 & 73 & 107 & 50 \\
\hline & $\mathrm{HU}$ & 473 & 5947 & 50 & & 83 & 189 & 6772 & 3245 & 5836 & 1756 \\
\hline & LV & 46 & 248 & 1596 & 189 & & 3238 & 1644 & 33 & 167 & 41 \\
\hline & LT & 92 & 666 & 1120 & 288 & 2613 & & 4203 & 106 & 202 & 129 \\
\hline & PL & 762 & 9151 & 333 & 4311 & 620 & 2178 & & 2420 & 4722 & 975 \\
\hline & RO & 2716 & 2863 & 132 & 6717 & 30 & 121 & 5440 & & 2242 & 766 \\
\hline & SK & 269 & 9635 & 39 & 4444 & 45 & 81 & 5123 & 1345 & & 416 \\
\hline & SI & 162 & 921 & 15 & 947 & 16 & 41 & 1021 & 553 & 538 & \\
\hline
\end{tabular}

Source: Authors' own elaboration based on UNCTAD data (2020). 


\section{References}

Adarov, A., Astrov, V., Grieveson, R., Holzner, M., \& Hunya, G. (2019). The economic development of Hungary and Austria in a Central European context: Past decades and future scenarios (Research Report, No. 443). Vienna: The Vienna Institute for International Economic Studies.

Albulescu, C. T., \& Goyeau, D. (2019). The interaction between trade and FDI: The CEECs experience. International Economics and Economic Policy, 16(3), 489-509. https://doi.org/10.1007/s10368-019-00438-1

Ambroziak, Ł. (2012). FDI and intra-industry trade: theory and empirical evidence from the Visegrad countries. International Journal of Economics and Business Research, 4(1-2), 180-198. https://doi.org/10.1504/IJEBR.2012.044252

Bafoil, F., \& Ruiwen, L. (2010). Re-examining the role of transport infrastructure in trade, regional growth and governance: Comparing the Greater Mekong Subregion (GMS) and Central Eastern Europe (CEE). Journal of Current Southeast Asian Affairs, 29(2), 73-119. https://doi.org/10.1177/186810341002900203

Bandara, J. S., \& Yu, W. (2003). How desirable is the South Asian Free Trade Area? A quantitative economic assessment. World Economy, 26(9), 1293-1323. https:// doi.org/10.1046/j.1467-9701.2003.00574.x

Baniya, S., Rocha, N., \& Ruta, M. (2019). Trade effects of the new silk road: A gravity analysis (Policy Research Working Paper, No. 8694). Washington: The World Bank. Retrieved from https://documents1.worldbank.org/curated/en/623141547 127268639/pdf/Trade-Effects-of-the-New-Silk-Road-A-Gravity-Analysis.pdf

Beugelskdijk, S., Smeets, R., \& Zwinkels, R. (2008, August). The impact of horizontal and vertical FDI on host's country economic growth. International Business Review, 17(4), 452-472. https://doi.org/10.1016/j.ibusrev.2008.02.004

Belka, M., \& Nagy-Mohacsi, P. (2020). COVID-19 may strengthen Central-Eastern Europe - will it embrace the EU or nationalism? Retrieved from https://blogs.lse. ac.uk/covid19/2020/06/15/covid-19-may-strengthen-central-eastern-europe-will-itembrace-the-eu-or-national

Beverelli, C., Keck, A., Larch, M., \& Yotov, Y. (2018). Institutions, trade and development: A quantitative analysis (Working Paper Series, No. 6920). Munich: CESifo.

Brahmbhatt, M. (1998). Measuring global economic integration: A review of the literature and recent evidence. Washington: The World Bank. Retrieved from https:// citeseerx.ist.psu.edu/viewdoc/download?doi=10.1.1.116.5900\&rep=rep1\&type=pdf

Buelens, C., \& Tirpák, M. (2017). Reading the footprints: How foreign investors shape countries' participation in global value chains. Comparative Economic Studies, 59(4), 561-584. https://doi.org/10.1057/s41294-017-0036-2

Cheptea, A. (2007). Trade liberalization and institutional reforms. Economics of Transition, 15(2), 211-255. https://doi.org/10.1162/ASEP_a_00001

Cheptea, A. (2013). Border effects and European integration. CESifo Economic Studies, 59(2), 277-305. https://doi.org/10.1093/cesifo/ifs035 
Chiacchio, F., Gradeva, K., \& Lopez-Garcia, P. (2018). The post-crisis TFP growth slowdown in CEE countries: Exploring the role of global value chains (Working Paper, No. 2143). Frankfurt am Main: European Central Bank (ECB).

Cieślik, A., \& Wciślik, D. R. (2020, December). Convergence among the CEE-8 economies and their catch-up towards the EU-15. Structural Change and Economic Dynamics, 55, 39-48. https://doi.org/10.1016/j.strueco.2020.07.006

Cieślik, E., Biegańska, J., \& Środa-Murawska, S. (2016). The intensification of foreign trade in post-socialist countries and their role in global value chains. Acta Oeconomica, 66(3), 465-487. https://doi.org/10.1556/032.2016.66.3.5

Cieślik, E., Biegańska, J., \& Środa-Murawska, S. (2019). Central and Eastern European states from an international perspective: Economic potential and paths of participation in global value chains. Emerging Markets Finance and Trade, 1-17. https://doi.org/10.1080/1540496X.2019.1602519

Damijan, J., Kostevc, Č., \& Rojec, M. (2015). Bright past, shady future? Past and potential future export performance of CEE countries in a comparative perspective. PostCommunist Economies, 27(3), 306-335. https://doi.org/10.1080/14631377.2015. 1055965

Daszkiewicz, N., \& Olczyk, M. (2014). Competitiveness of the Visegrad countries paths for competitiveness growth. In D. Kiendl-Wender, K. Wach, FH Joanneum (Eds.), International Competitiveness in Visegrad Countries: Macro and Micro Perspectives (pp. 33-52). Graz: Fachhochschule Joanneum. Retrieved from http://www.visegrad.uek.krakow.pl/PDF/Graz2014_ch02_daszkiewicz_olczyk.pdf

Éltetö, A. (2014). Foreign trade trends in the EU10 countries. In A. Éltető (Ed.), Mind the gap, integration experiences of the ten Central and Eastern European countries (pp. 41-60). Pécs: Institute for World Economics, Centre for Economic and Regional Studies, Hungarian Academy of Sciences. Retrieved from https://core. ac.uk/download/pdf/42929998.pdf

European Parliament. (2017). Understanding non-tariff barriers in the single market. Retrieved from https://www.europarl.europa.eu/RegData/etudes/BRIE/2017/6087 47/EPRS_BRI(2017)608747_EN.pdf

European Commission. (2021). Free movement in harmonized and non-harmonised sectors. Retrieved from https://ec.europa.eu/growth/single-market/goods/freemovement-sectors_en

Francois, J., \& Manchin, M. (2013, June). Institutions, infrastructure, and trade. World Development, 46, 165-175. https://doi.org/10.1016/j.worlddev.2013.02.009

Gereffi, G. (2014). Global value chains in a post-Washington Consensus world. Review of international political economy, 21(1), 9-37. https://doi.org/10.1080/09692290. 2012.756414

Globerman, S., \& Shapiro, D. M. (2008). Outward FDI and the economic performance of emerging markets. The rise of transnational corporations from emerging markets: threat or opportunity. In K. P. Sauvant (Eds.), The rise of transnational corporations from emerging markets (pp. 312-340). Cheltenham: Edward Elgar Publishing. 
Grela, M., Majchrowska, A., Michałek, T., Mućk, J., Stążka-Gawrysiak, A., Tchorek, G., \& Wagner, M. (2017). Is Central and Eastern Europe converging towards the EU-15? (Working Paper, No. 264). Warszawa: Narodowy Bank Polski (NBP). Retrieved from https://www.nbp.pl/Publikacje/Materialy_I_Studia/264_En.Pdf

Gruševaja, M. (2015). Synthesis report: WP7. Dynamics of institutional convergence (Working Paper Series, No. 7). Pécs: GRINCOH. Retrieved from http://www. grincoh.eu/media/syhtnesis_reports/grincoh_wp7_synthesis_report_grusevaja.pdf

Hanousek, J., \& Kočenda, E. (2014, December). Factors of trade in Europe. Economic Systems, 38(4), 518-535. https://doi.org/10.1016/j.ecosys.2014.06.001

Hanzl-Weiss, D., Leitner, S. M., Stehrer, R., \& Stöllinger, R. (2018). Global and regional value chains: How important, how different? [Research Report, No. 427]. Vienna: The Vienna Institute for International Economic Studies.

Iapadre, L., \& Plummer, M. (2011). Statistical measures of regional trade integration. In P. De Lombarde, R. Flores, L. Iapadre, \& M. Schulz (Eds.), The regional integration manual: Quantitative and qualitative methods (pp. 98-123). London: Routledge.

Iossifov, P. K. (2014). Cross-border production chains and business cycle co-movement between Central and Eastern European countries and euro area member states (ECB Working Paper, No. 1628). Frankfurt am Main: European Central Bank.

Kang, Y. D. (2010). Intra-industry trade in an enlarged Europe: Trend of intra-industry trade in the European Union and its determinants [KIEP Research Paper, No. 10-02]. Seul: Korea Institute for International Economic Policy. https://doi.org/10.2139/ ssrn. 2488878

Kawecka-Wyrzykowska, E. (2009). Evolving pattern of intra-industry trade specialization of the new Member States (NMS) of the EU: the case of automotive industry [Economic Policy, No. 364]. Brussels: European Commission, Directorate General Economic and Financial Affairs (DG ECFIN).

Kofner, A. (2020). Intra-union trade loosing importance for EU countries. Retrieved from https://12v.blogactiv.eu/2020/04/19/intra-union-trade-loosing-importance-foreu-countries/

Laaser, C. F., \& Schrader, K. (2002). European integration and changing trade patterns: The case of the Baltic States [Working Paper, No.1088]. Kiel: Kiel Institute for World Economy. Retrieved from https://www.ifw-kiel.de/publications/kielworking-papers/european-integration-and-changing-trade-patterns-the-case-of-thebaltic-states/

Leitner, S. M., \& Stehrer, R. (2014). Trade integration, production fragmentation and performance in Europe-blessing or curse? A comparative analysis of the New Member States and the EU-15 [WIIW Research Report, No. 397]. Vienna: Vienna Institute for International Economic Studies. Retrieved from https://ideas.repec.org/ p/wii/rpaper/rr397.html 
Marius-Corneliu, M. (2013). Trade integration of the Central and Eastern European economies with the euro area. Ovidius University Annals, Series Economic Sciences, 13(1), 215-219. Retrieved from https://ideas.repec.org/a/ovi/oviste/vxiiy2012 i1p215-219.html

Martínez-San Román, V., Bengoa, M., \& Sánchez-Robles, B. (2016). Foreign direct investment, trade integration and the home bias: Evidence from the European Union. Empirical Economics, 50(1), 197-229. https://doi.org/10.1007/s00181-0150942-y

Martínez-Zarzoso, I., Voicu, A. M., \& Vidovic, M. (2015). Central East European countries' accession into the European Union: Role of extensive margin for trade in intermediate and final goods. Empirica, 42(4), 825-844. https://doi.org/10.1007/ s10663-015-9279-1

Molendowski, E. (2007). „CEFTA 2006” - jej znaczenie dla liberalizacji handlu w krajach Europy Środkowej i Wschodniej [“CEFTA 2006” and its role in trade liberalization in Central and Eastern European countries]. Wspólnoty Europejskie, 4(185), 5-11.

Molendowski, E. (2012). Integracja handlowa w nowych państwach członkowskich (UE-10) [Trade integration in the New Member States (EU-10)]. Warszawa: Difin.

Mongelli, F. P., Dorucci, E., \& Agur, I. (2005). What does European institutional integration tell us about trade integration? [ECB Occcasional Paper, No. 40]. Frankfurt am Main: European Central Bank. Retrieved from https://www.ecb.europa.eu/ pub/pdf/scpops/ecbocp40.pdf

Moroianu-Dumitrescu, N., \& Novac, A. (2020). Trade integration in EU - a win-win process. Romanian Statistical Review - Supplement, 4(95), 94-117. Retrieved from https://www.revistadestatistica.ro/supliment/wp-content/uploads/2020/04/rrss_04_ 2020_A3_EN.pdf

Nilsson, L. (2000, November). Trade integration and the EU economic membership criteria. European Journal of Political Economy, 16(4), 807-827. https://doi. org/10.1016/S0176-2680(99)00060-9

Nordås, H. K., \& Piermartini, R. (2004). Infrastructure and trade [WTO Staff Working Paper, No. ERSD-2004-04]. Geneva: World Trade Organization.

Olczyk, M., \& Kordalska, A. (2017). Gross exports versus value-added exports: Determinants and policy implications for manufacturing sectors in selected CEE countries. Eastern European Economics, 55(1), 91-109. https://doi.org/10.1080/00128 775.2016.1254564

Portugal-Perez, A., \& Wilson, J. S. (2012, July). Export performance and trade facilitation reform: Hard and soft infrastructure. World Development, 40(7), 1295-1307. https://doi.org/10.1016/j.worlddev.2011.12.002

Ravishankar, G., \& Stack, M. M. (2014, May). The gravity model and trade efficiency: A stochastic frontier analysis of Eastern European countries' potential trade. The World Economy, 37(5), 690-704. https://doi.org/10.1111/twec.12144 
Sobański, K. (2015). Trade linkages between CEE countries and the world economy during an era of global imbalances. Studia Ekonomiczne. Zeszyty Naukowe Uniwersytetu Ekonomicznego w Katowicach, 226, 124-137. Retrieved from https:// www.ue.katowice.pl/fileadmin/_migrated/content_uploads/10_22.pdf

Tabellini, G. (2010, June). Culture and institutions: Economic development in the regions of Europe. Journal of the European Economic Association, 8(4), 677-716. https://doi.org/10.1111/j.1542-4774.2010.tb00537.x

United Nations Conference on Trade and Development [UNCTAD]. (2020). Imports of individual economies. Retrieved June 10, 2020 from https://unctadstat.unctad. org/wds/ReportFolders/reportFolders.aspx?fbclid=IwAR2KoEpGkHrGsy7iiHq8_aI 9KxKHoWClCW2I01dw5axyX4OirdoVWCFxk8E

Wilhelmsson, F. (2006). Trade creation, diversion and displacement of the EU Enlargement process. Retrieved September 15, 2020, from http://www.pro-clasic. com/ethnicgv/TA/pdf/200606\%20Trade\%20Creation,\%20Diversion\%20and\%20Di splacement $\% 20 \mathrm{of} \% 20$ the $\% 20$ EU\%20Enlargement $\% 20$ Process.pdf

World Bank. (2020). GDP per capita, PPP (current international \$). Retrieved from https://data.worldbank.org/indicator/NY.GDP.PCAP.PP.CD?end=2019\&most_rece nt_year_desc $=$ true\&start $=1990 \&$ view $=$ chart

World Trade Organization [WTO]. (2013). World Trade Report 2013: Factors shaping the future of world trade. Geneva: World Trade Organization.

Zaki, C. (2015). How does trade facilitation affect international trade? The European Journal of Development Research, 27(1), 156-185. https://doi.org/10.1057/ejdr. 2014.36

Zaman, G. (2008). Economic effects of CEE countries integration into the European Union. Economic Sciences Series, 60(4), 45-54. 